\title{
Bosnia: Prelude, Disease, and Sequelae
}

\begin{abstract}
In Bosnia, three factors led to war: the breakup of former Yugoslavia, Slobodan Milošević's political ambitions and military capability, and ethnic nationalism, particularly in its territorial form. It is hard to picture the Bosnian War without any one of these. It is hard to picture peace prevailing with all three. After an initial period of stalemate, the postwar process in Bosnia benefited for almost ten years from ample international commitment of political will and other resources, blocking of Croatia's support for Croat separatism inside Bosnia, and co-optation of Bosnian elites. The state- and peace-building process stalled thereafter, as the Americans passed the baton to a Europe that fumbled it. Bosnia is still not yet safe from nationalist and Russian destabilization.
\end{abstract}

Keywords Dayton peace agreements • Ethnic cleansing • High Representative

Former Yugoslavia was a weak state. ${ }^{1}$ It lacked legitimacy with its people, its inefficient socialist economic system was creaking, and leaders of its multiple ethnic groups were developing separate "national" cultural and historical narratives that competed with Yugoslav identity, which had a tenuous hold once Tito died in 1980. The fall of the Berlin Wall undermined the centralized authority of the Communist Party that still held Yugoslavia together, albeit tenuously. The dominant "Socialist" ideology

(C) The Author(s) 2019

D. Serwer, From War to Peace in the Balkans, the Middle East and Ukraine, Palgrave Critical Studies in Post-Conflict Recovery, https://doi.org/10.1007/978-3-030-02173-3_3 
was cosmopolitan and multiethnic but still autocratic. Internal opposition to it was largely organized along ethnic lines, starting in the late 1960s. Each of what Yugoslavs called the "national" (ethnic) narratives included a large slice of persecution by the others: Serbs by Albanians in Kosovo; Croats, Slovenes, and Bosniak Muslims by Serbian political, linguistic, and cultural hegemony throughout Yugoslavia; and Albanians by being excluded and marginalized politically and culturally in Kosovo, Serbia, and Macedonia.

Milošević had made a career entirely as an apparatchik within the Yugoslav communist hierarchy. ${ }^{2} \mathrm{He}$ was late to the nationalist discourse, but he adopted it, initially to recentralize the Yugoslav state, and later to acquire power in Serbia and preserve as much of Yugoslavia as possible under Serbian rule. Late though he was, Milošević was ruthless in using Serbian nationalism to reestablish tight control over Vojvodina and Kosovo, the two autonomous provinces inside Serbia, as well as over Montenegro, one of the six republics that made up Yugoslavia when it was reestablished in the wake of World War II. Had Serbian nationalism remained an intellectual movement of the sort espoused in the Serbian Academy's draft memorandum, it is doubtful it could have played any significant role in breaking up Yugoslavia. But Milošević was able to translate this academic language into a rallying cry that mobilized Serbs against the autonomous provinces, against the federal government, against the other republics, and in favor of a country dominated by Serbs. He had the territorial ambition and military capability to back up the rhetoric.

Slovenia, where few Serbs lived, was the most prosperous of Socialist Yugoslavia's six republics and the keystone of their federation. Once the Berlin Wall fell, Slovenes were no longer prepared to see their finances drained to benefit Yugoslavs who lived in Macedonia and Kosovo. They voted for independence in a December 1990 referendum. The Yugoslav National Army (JNA) lost the ten-day war that ensued. Milošević withdrew it to concentrate on republics where Serbs were a larger proportion of the population.

Inter-ethnic violence in Croatia was already on the rise. Led by Franjo Tuđman, a JNA general turned Croat nationalist historian, Zagreb followed Ljubljana in organizing and approving secession from Yugoslavia in May 1991. Many Serbs, including in the United States, believe that Washington conspired with Ljubljana and Zagreb to dismantle former Yugoslavia. But that was not the case. In Belgrade in June 1991 
Secretary Baker even said publicly that Washington would not recognize Slovenian or Croatian independence "under any circumstances." ${ }^{3} \mathrm{He}$ was still trying to avoid what soon became inevitable. By early 1992, the Maastricht Treaty had created the European Union (previously known as the European Community) and its Common Foreign and Security Policy. Germany insisted that other EU members recognize Slovenia and Croatia or risk scuttling the newly created Union. Even Rome and London, which almost always found ways of following the American lead on important issues, instead defied Washington and complied with Germany's diktat. So too did the rest of the EU.

Bosnia and Macedonia might both have preferred to stay in Yugoslavia, but with the exit of Slovenia and Croatia it was clear that Milošević and Serbian nationalism would dominate whatever was left of the Yugoslav Federation. Bosnian President Alija Izetbegović had not advocated an independent Bosnia or, as charged in the 1980s in a Yugoslav court, an ethnically cleansed Muslim territory, or as charged later, an Islamic Republic. ${ }^{4}$ His Islamic Declaration was about Muslim moral regeneration and education in the modern world, not politics. He was acutely aware that Bosnia lacked an army and would face daunting odds if it tried to secede. ${ }^{5}$

But Izetbegović was not in control of events. Slovenia and Croatia were already independent. With little provocation, Serb-majority parts of Bosnia had called for help and protection from Belgrade, which provided ample support through the JNA. In January 1992 the nationalist Serbs conducted their own referendum to secede from a Bosnia that was not yet independent. This pattern - a minority population that constitutes a majority on particular territory calling on its "mother" country for protection and conducting a referendum on secession-is a classic irredentist technique that would be repeated decades later in Crimea.

Aiming to promote liberal democracy based on individual rights throughout the Balkans, the Badinter Commission, a creature of the International Conference on Yugoslavia, had established a majority referendum in each Yugoslav republic as one of several prerequisites for independence. ${ }^{6}$ Brussels accordingly insisted on a majority-rules referendum in all of Bosnia, held on February 29 and March 1, 1992. Virtually $100 \%$ voted for independence, but only $63.4 \%$ of registered voters went to the polls, most of whom were Bosniaks and Croats. Many Serbs boycotted, believing that would invalidate the result, an expectation based 
on the group-rights practice of Socialist Yugoslavia. Ethnic cleansing of Muslims and Croats from Serb-dominated areas that claimed to have seceded (based on a referendum in which Muslims and Croats had not participated) had already begun. Izetbegović, who lacked an army, nevertheless went ahead and declared independence almost immediately, likely hoping that would bring international help. War was on.

It was a brutal, lengthy, and deadly disaster. The highlights tell only a small fraction of the story: one hundred thousand people killed, half the population displaced from their homes, town centers reduced to rubble by small-arms fire, Sarajevo nearly split in two and almost defeated in the first weeks, then under siege and bombarded for three long years, Izetbegović kidnapped and exchanged for a JNA military contingent attacked by a still rudimentary Bosnian Army while under UN protection, the murder of more than seven thousand Muslim males captured in the UN-protected "safe area" of Srebrenica." Croats and Bosniaks began the war united in favor of an independent Bosnia, but from June 1992 until February 1994 they fought against each other in central and southern Bosnia even while fighting together against the Serbs along the Posavina corridor in the north. Tuđman and Milošević might have liked to divide Bosnia between them, but they had no idea what to do with the Bosniak population except chase it from territory Croats and Serbs controlled, which threatened to create the conditions for an Islamic statelet (or two) in central Bosnia.

Europe and the UN had tried to find a solution to the conflict even before it broke out. In this case, prevention as well as their efforts after the outbreak of war failed, because the means available were not sufficient to meet the challenge. ${ }^{8}$ In 1991, while trying to negotiate an end to the Slovenian war for independence, EU President Jacque Poos declared that "the hour of Europe has dawned." It turned out to be a long and dark hour in Bosnia, as the Europeans were not prepared to intervene militarily and the Americans were focused elsewhere. ${ }^{9}$ Initiatives like the Owen/Stoltenberg and Vance/Owen plans, which in many respects foreshadowed the eventual power-sharing settlement reached at Dayton, not only failed to bring about an end to the war but likely caused ethnic cleansing by identifying parts of the country that would be designated "Croat," "Serb," and "Bosniak." 10 Courageous Europeans staffing the EU's own monitoring mission as well as a large part of the UN peacekeeping force could do nothing to alter the long stalemate that persisted from 1992 until NATO intervened in 1995. 
They reported on what was going on and protected humanitarian convoys, but little more.

The UN and the Americans did a bit better. In early 1994 they cooperated in convincing Tuđman that chasing the Bosniaks from Croat-dominated areas would create something he would not like on his borders. In the State Department it was called "a non-viable, rump Islamic Republic that would be a platform for Iranian-sponsored terrorism in Europe." Islamic terrorism in the United States had not yet been invented, even in our imaginations. Nor was extremism common among Bosnian Muslims. Tuđman was fond of claiming that civilization stopped at the Sava, the river that forms the northern border of Bosnia and Croatia. The Americans wondered on which side of the Sava it stopped. Asked if they are Sunni or Shia, Bosniaks often reply with puzzlement, No, we are Bosnian. But after three years of war in which people were killed because they were Muslim, there was a small but growing group of radicals, in addition to hundreds of people the Americans called "muj" (mujahideen) who had come from abroad to assist. Initially multiethnic, the Bosnian Army had become an almost entirely Bosniak army. ${ }^{11}$ After the war, NATO raided at least one terrorist training facility.

To avoid a rump Islamic state, Washington proposed Tuđman cooperate with the Muslims in fighting the secessionist Serbs. The deal was sweetened with the one-quarter to one-third of the arms the Croatians skimmed from shipments to the Bosnian Army from Turkey, Iran, Malaysia, and other countries, in contravention of a UN arms embargo. The Americans turned a blind eye to the arms smuggling, hoping to strengthen both Croat and Bosniak forces for the fight against the Serbs. ${ }^{12}$ In public the Americans said they were trying to preserve multiethnic democracy in Bosnia, but this idealistic formulation was combined, at least for the realists, with prevention of terrorism.

That perspective still has validity today: any partition of Bosnia would necessarily be at least three-way, leaving one if not two rump Islamic states at its center (surrounding Bihać and Sarajevo). Multiethnicity is now the less compelling argument, as the wars in Bosnia homogenized much of its population. But potential radicalization is a far stronger argument than it was twenty years ago, as Islamist extremism has grown as a threat to both the United States and Europe. Bosnia's contribution to foreign fighters in Syria and Iraq includes both extremists who fought in the 1990 s and more recent recruits. ${ }^{13}$ 
The political outcome of Tuđman's recognition of the risk of creating an Islamic state was the Bosnian Federation: a constitutional arrangement between the Croats and Bosniaks intended to govern on at least $51 \%$ of the territory, eventually to be confederated to Croatia (a promise never fulfilled). ${ }^{14}$ The other $49 \%$ was to be the "other entity": Republika Srpska (Serb Republic, to be distinguished however from the Republic of Serbia, Bosnia's neighbor to the east with its capital in Belgrade). The Serbs might also have benefited from an arrangement with the Bosniaks like the one the Croats had, but Milošević was never convinced of what today is obvious to all the Serbian foreign ministry officials: partition of Bosnia resulting in an Islamic republic is a terrible idea. ${ }^{15}$

The Federation was a military success. Amity between Croats and Bosniaks was not the basis for its advances in the summer of 1995. The mostly Muslim Bosnian Army and the mostly Catholic Croat Defence Council (HVO) both fought against the Serbs but competed for territory. They assumed they would be able to keep whatever they conquered. Neither would have succeeded alone or without NATO air attacks and the Croatian Army, which not only supplied the HVO but also commanded it.

NATO's contribution was the bombing of the Bosnian Serb Army (VRS), precipitated in August 1995 by shelling of Sarajevo. That triggered what were known as the "Goražde rules," which required a NATO response if any of the six UN-protected areas in Bosnia were attacked. ${ }^{16}$ This agreed trip wire precipitated action. But NATO quickly ran out of primary and secondary targets when the Serbs parked their armor and artillery next to mosques and schools. When it turned to lowerpriority targets it started hitting the communication nodes of the VRS, which were vital to the ability of its relatively small force to counter the much larger Bosnian Army along a lengthy confrontation line. The VRS retreated rapidly. ${ }^{17}$ The Federation forces, which had controlled less than $30 \%$ of the territory during more than three years of war, soon overran more than two-thirds.

This is where "Dayton" comes in. The word has come to signify the end of the seemingly intractable violence in Bosnia from 1992 to 1995. The narrative surrounding it is powerful: after everyone else (the UN, the Europeans) had tried and failed, the United States intervened with military force and an American diplomat took the warring parties off to an isolated air force base in Ohio, where he bent them to his will and ended the war. ${ }^{18}$ Holbrooke left no doubt that the critical moment was 
when Yugoslav President Slobodan Milošević agreed to accept peace with the Federation (Bosniak and Croat) forces arrayed against him and the army of Republika Srpska. ${ }^{19}$ This was the triumph of American statecraft, force, and will, wielded together in a good cause against a destructive force.

The "Dayton" narrative is powerful but inaccurate and misleading. ${ }^{20}$ It has led diplomats down the wrong paths ever since, causing them to overestimate the decisiveness of the use of force, which was necessary but not sufficient. Holbrooke's team interpreted what had happened as Milošević's reaction to the NATO bombing of the Serb forces in Bosnia. But Milošević did not care much about the Serb forces in Bosnia, which were mainly loyal not to him but to the Bosnian Serb leader Radovan Karadžić, who at the time was regarded as a potential rival to Milošević in Belgrade, if Republika Srpska were to become part of Serbia. ${ }^{21}$ Belgrade had run out of the money needed to finance the war in Bosnia. Milošević wanted sanctions lifted. ${ }^{22}$

The reality of Dayton was thus different from Holbrooke's narrative. Milošević came to Dayton suing for peace. ${ }^{23} \mathrm{He}$ was responding not to the bombing per se but rather to a threat to his own hold on power. He had believed that the Serbs in Croatia could hold their own against the Croatian Army. ${ }^{24}$ They failed. As a result, something like two hundred thousand Serbs had walked out of Croatia into Serbia only a few months earlier, when Zagreb launched its Operation Storm to regain control of UN-Protected Areas in Croatia. By late September 1995, the Federation forces were routing the VRS. Milošević told the Americans he was concerned about another flood of refugees. Anyone who took that as an expression of humanitarian consciousness had misunderstood. What really concerned Milošević was the prospect of another five hundred thousand (or more) Serbs walking out of Bosnia into Serbia, where they would have joined the Croatian Serbs in calling for his ouster. ${ }^{25}$

When Milošević came to Dayton he needed an agreement and the sanctions relief he had been trying to negotiate with the Americans for months, unsuccessfully. ${ }^{26}$ Imposition of the sanctions years earlier had not much affected him. This is typical: sanctions rarely have an immediate effect, but their removal can be a powerful incentive. ${ }^{27}$ For Milošević, sanctions relief became urgent as the tide of war turned against his forces. But the man was cagey and feigned resistance until the last moment, a standard Balkans practice, getting in the process a good 
deal for Republika Srpska that undermined his rival Karadžić, whom the Americans and Milošević had arranged to exclude from Dayton.

Milošević's gains included $49 \%$ of the territory of Bosnia and Herzegovina, forcing the Federation forces to roll back from the more than two-thirds that they controlled when the cease-fire finally went into effect. He also got international acceptance of Republika Srpska, an "entity" defined by its majority Serb population, even though its territory was not majority Serb before the war. Autonomous and entitled to special relations with Serbia, Republika Srpska kept its army, police, and other security forces, which were saved from almost certain defeat. The central government (in Bosnia called the "state" government) had few functions, the execution of which was constrained by ethnically based vetoes. These power-sharing arrangements were codified in a difficult-to-amend, permanent constitution that the Americans insisted upon, fearing that anything easier to revise would lead to partition. All armies and ethnic nationalists on the verge of defeat should have the good fortune to be hauled off to "Dayton."

The Croats also got a very good deal at Dayton. Tuđman was in the driver's seat, as the successful Federation offensive was due in part to his forces backing up as well as commanding the Bosnian Croats. He controlled the only routes into the Bosniak areas of central Bosnia and skimmed off arms there. The Croats got what they asked for: half the Federation and one-third of the state government in Sarajevo, even though they had been only $17 \%$ of the population before the war and were certainly far less than that at the time of Dayton. They are now officially $15.4 \%$ of a significantly reduced total population, while Bosniaks are $51.1 \% .^{28}$

The Croats also asked that the Americans get the Bosniaks to expel the foreign mujahideen imported to fight in some units of the Bosnian Army. When asked how many there were, Jadranko Prlić-then the "defense minister" associated with the Croat parastate known as "Herzeg-Bosna," created to govern on HVO-controlled territory during the war-said seven hundred. ${ }^{29}$ This should be regarded as an upper limit of the number, which in subsequent years has been grossly inflated into the thousands by those who want to portray Bosnia as a haven for Muslim extremists. For months after Dayton, the CIA produced regular reports on whether the Bosniaks were complying. Half of the "muj" were forced to leave Bosnia. Some were difficult to expel because they had married Bosnians and had Bosnian children. When asked whether 
the CIA would produce comparable reports on expulsion of non-Bosnian Serbs (mainly from Serbia) who led and staffed units of the VRS, the answer was no. Getting rid of foreign fighters meant Muslims, not Serbs or Croats.

It wasn't Milošević's or Tuđman's arm that Holbrooke needed to twist at Dayton. It was Izetbegović's. The Bosniak president said it clearly at the initialing of the Dayton agreements, as he had previously to Holbrooke in private: "It is not a just peace ... but my people need peace." 30 In addition to the weakened power-sharing government in Sarajevo, Izetbegović was forced to accept Republika Srpska on nearly half the country's territory in exchange for a promise that all refugees and displaced people would be able to return to their homes. He certainly knew how difficult that promise would be to fulfill in an entity that defined itself as "Serb" and had removed most of its non-Serb population during the war. Republika Srpska, which in 2013 was more than $80 \%$ Serb, would not be majority Serb if everyone were to return to their prewar homes. Dayton confirmed Serb military successes that were in danger on the battlefield. Izetbegović was a man of few and bitter words, but not a fool.

Snatching defeat, or at least a mixed result, from the jaws of victory is the phrase that comes to mind. Why did the Americans do it? Anxious to end the war, they believed that a temporary compromise with territorial ethnic nationalism could be converted eventually to a more liberal democratic order. ${ }^{31}$ Why did Izetbegović allow it? America was his ally and chief, though not only, diplomatic backer in the war. They made it clear they would not continue to support him if he refused the settlement. Izetbegović assumed that Washington could turn off the Saudi money that flowed into his bank account. The story Holbrooke's team told him-that U.S. intelligence sources had concluded that Serb resistance was stiffening and would throw back the Federation offensivewould have sounded plausible to Izetbegović, as the Bosnian Army overextended itself several times during the war and suffered ignominious defeats as a result. But this time the story was made up out of whole cloth. ${ }^{32}$ In addition, the Americans offered Izetbegovic something he found hard to turn down: a massive "equip and train" program for the Federation armed forces that would at least guarantee that something like the stalemated 1992-1995 war would not happen again. Once the Americans had convinced Milošević and Tuđman to sign on, Izetbegović could not be the odd one out. 
Dayton, rather than being a triumph of American diplomacy in a good cause, is more like an object lesson in why you should not be America's best friend. If you are, the Americans find it easier to twist your arm than that of your enemy. There was no bright new idea in the Dayton agreements. They largely confirmed governing arrangements that already existed at the entity level and superimposed a weak central government based on power sharing among former warring parties. Holbrooke's key contribution was not conceptual but rather his ability to point all the levers of American power in the same direction at the same time. Secretaries of state and even presidents have difficulty doing that, never mind an assistant secretary of state. The situation was not naturally "ripe" for resolution. Neither a mutually hurting stalemate nor a mutually enticing opportunity, which scholars view as preconditions for a negotiated agreement, existed in Bosnia before the Dayton talks. Holbrooke ripened the situation by making it impossible for Izetbegović to continue fighting, while providing Milošević and Tuđman with good reasons to stop.

The main issues resolved at Dayton were territorial and constitutional: the agreements separated the Federation and Republika Srpska by an "inter-entity boundary line." Dayton also imposed power-sharing arrangements and mutual vetoes, without, however, any provision for improving inter-ethnic relations. The agreements included provisions for transitional justice, to be conducted mainly by the International Criminal Tribunal for the former Yugoslavia in The Hague, but little else to give an accounting for what had happened and why. Dayton validated the existence of Republika Srpska, abolished the Yugoslav-origin Bosnian Republic that Izetbegovic had led during the war, and enabled the ethnic nationalists responsible for the war to remain in power. Negotiated agreements necessarily involve painful compromises. Many of Bosnia's postwar problems stem directly from the power-sharing arrangements that diplomats and scholars think so necessary to negotiating an end to civil wars. ${ }^{33}$

Now it is more than two decades years later. Even if the peace was not just, or warm, it was the absence of war and it has held. What can we learn from the postwar experience? First and foremost is that implementation is as important as the peace agreement. There had been no peace process to speak of leading up to Dayton. What we normally think of as the peace process - the warring parties getting to know each other, learning their adversary's language and tricks, finding out what is feasible and 
what is not, learning what they can trust and not-happened in Bosnia mostly after the signing, not before. The Americans-who believed that civilian interference in military operations was a major cause of UN failure in Bosnia from 1992 to 1995-insisted at Dayton that the NATO military commander in Bosnia report exclusively through the normal NATO command to the (American) Supreme Allied Commander. This was intended to prevent "mission creep" and civilian interference as well as fend off the French, who were then not participating in the NATO military chain of command and wanted it modified to suit their preferences in Bosnia. This sharp division between the international civilian and military efforts severely hampered what became known as "Dayton implementation."

The Europeans were put in charge of the civilian side, intentionally kept as separate as possible, through an international community High Representative, initially Carl Bildt, former prime minister and future foreign minister of Sweden. While they later came to appreciate Bildt, at Dayton the Americans were anxious to exclude him from anything that might prove important, especially military implementation of the agreement. Not surprisingly, many of the most severe problems in the first years after the war arose precisely in the interface between military and civilian responsibilities, which the Americans were so desperate to separate. Capture of war criminals, return of displaced people and refugees, and freedom of movement required tight coordination between military and civilians, not strict separation. The turnover of the so-called "Serb suburbs" of Sarajevo to the Federation was an early indicator of how difficult things would be. None of these areas had more than a plurality of Serbs before the war, and one area was adjacent to downtown. The Republika Srpska authorities asked for and got permission from NATO to keep their police in these areas, claiming that this would encourage Serbs to stay. They then used the police to "self-cleanse" Serbs, moving them out of Sarajevo in NATO-supplied vehicles while burning and flooding high-rise apartments so that they would be uninhabitable. ${ }^{34}$

Implementation of the Dayton agreements in the first couple of years proved too hard. ${ }^{35}$ Republika Srpska tried to prevent the Sarajevo state government that the Dayton accords created from any sort of authority in the $49 \%$ of the territory it controlled. The Bosnian Croats tried to preserve their separate wartime "Herzeg-Bosna" institutions. The Bosniaks tried to push return of displaced Muslims into strategically sensitive areas in Republika Srpska and Herzeg-Bosna, even while they resisted returns 
of Croats and Serbs to Sarajevo. As a result, in December 1997 the Peace Implementation Council, the committee of governments that still oversees the peace process, granted to the High Representative "Bonn powers" to issue legislation and to remove officials from office. The powerless High Representative became a virtual autocrat charged with preserving the peace and getting Bosnia to democracy.

Then began an intensive period of civilian peace implementation under European leadership with strong American backing, beginning with Wolfgang Petritsch (1999-2002) and culminating with Paddy Ashdown (2002-2006) as High Representative. Some of Bosnia's war criminals were removed from office, the Sarajevo state government was strengthened, decently organized elections were held repeatedly, the armed forces were shrunk and mostly unified, the police were reformed and vetted more than once, the central bank and currency were established, some displaced people and refugees returned home, and property rights were clarified. Ashdown dismantled Herzeg-Bosna, thus blocking the worst of Croatia's meddling. ${ }^{36}$ Nothing comparable was done with Serbia, which continued to wield undue influence in Republika Srpska. The economy grew rapidly for several years after Dayton from its low wartime base, and by the time of the international financial crisis in 2008 it had reached about three times its GNP at the end of the war, making Bosnia an "upper middle income" country. ${ }^{37}$ With a lot of heavy lifting by the Americans, Bosnia even had an avowedly anti-nationalist prime minister for a year or so. The Europeans provided most of the aid Bosnia required, most of the troops for the "implementation force" and later the "stabilization force" NATO deployed, and most of the international police. Anyone who doubts the usefulness of NATO and European allies to the United States has not learned from the Balkans experience.

The implementation process was agonizing but at least partly successful, due to a lot of international pressure. Jacques Klein, the American head of the UN's International Police Task Force, mounted a successful scheme to reissue all the license plates, with only the letters common to the Cyrillic and Latin alphabets and no other identifying characteristics, even though they were manufactured in three different parts of the country. Freedom of movement ensued, because no one could tell your ethnicity from your license plates. A 1999 arbitration decision resolved the status of the northeastern town of Brčko, site of some of the war's worst horrors. ${ }^{38}$ It belonged, arbitrator Roberts Owen decided, to both the Federation and Republika Srpska, a smokescreen that effectively 
removed it from both while allowing each to claim victory. American "supervisors" had significant success there as well, while postponing elections entirely for seven years. ${ }^{39}$ They had learned that elections in Bosnia, as in many postwar societies, are highly conflictual and tend to increase ethnic division.

But it was clear by 2005, when the Council of Europe's Venice Commission issued a damning report on the Bosnian constitution, that what had been done at Dayton to end the war was inadequate to build a functioning European state. ${ }^{40}$ Bosnia needed constitutional reform. That meant revising the Dayton agreements, as the constitution was their mainstay. Don Hays, a former deputy to Ashdown, led the State Department-funded effort at the United States Institute of Peace, with Bosnians representing all the major political parties. Supported by American lawyers from the Public International Law and Policy Group, they discussed amendments to the Dayton constitution intended to reduce its elaborate power-sharing arrangements, make the Bosnian state more functional, and enable it to prepare for EU membership. This was co-optation at its best.

The proposal they produced-later known in a modified version as the "April package" - was less than many hoped for but still a reasonable start at fixing a constitution that had gone too far in enshrining ethnic identity and group rights as the be-all and end-all of Bosnian politics, making the country dysfunctional. ${ }^{41}$ The package clarified group, individual, and minority rights as well as mechanisms for protecting the "vital national interests" of Bosnia's constituent peoples. It also included reforms to strengthen the state government and the powers of the prime minister, reduce the presidency's responsibilities, and streamline parliamentary procedures. Most importantly, the amendments included a provision that gave the state government the authority it needed to negotiate and implement the requirements of EU membership. The April package was a down payment on broader reforms that were needed to disentangle the many interlocking vetoes that ensured power sharing immediately after the war but later plagued efforts to govern Bosnia effectively. When it failed by just two votes to gain the twothirds approval it needed in the Bosnian parliament in 2006, it seemed reasonable to expect it to return the next year and be passed with minor revisions.

That turned out to be wrong. The problem was not the two votes, which belonged to Croats who broke party discipline to vote against 
the package. It was more serious. Former wartime Prime Minister Haris Silajdžić, whose Bosniak-based party had participated in preparation of the constitutional amendments and had even chaired key meetings, staked his presidential campaign on turning down the April package, which he claimed changed too little and created a loophole that risked leaving Bosnia without a government. When he won the presidency, he refused to reverse himself and took up the cudgels against Republika Srpska leader Milorad Dodik, polarizing Bosnian politics along ethnic lines far more than had been the case in the decade since 1996. Dodik, who had been a relative moderate, began talking about independence and sovereignty for Republika Srpska, Silajdžić denounced its genocidal origins, and the more nationalist Croats revived their idea of the "third entity." Local elites do not always remain co-opted. When one adopts a nationalist narrative, others respond in kind.

Ten years of gradual progress ended in a fit of ethnic nationalist politics. Unhappily, it was just at this moment that the Europeans decided to send a German politician, Christian Schwarz-Schilling, to Bosnia as High Representative. He reflected European thinking that there had been too much international pressure on the Bosnians, especially from the Americans. ${ }^{42} \mathrm{He}$ wanted to encourage more "local ownership" and put aside the Bonn powers. The April package amendments have never returned for a vote in parliament. Even after the European Court of Human Rights ruled in 2009 against the Bosnian constitution's ethnic criteria for presidential candidates, the political leadership was unable to find a way of fixing the problem, which is easily solved if you are not committed to ethnic nationalism. ${ }^{43}$

Rejection of the April package began a long downhill slide for Bosnia. The Europeans have pushed aside the well-informed and well-meaning High Representatives who succeeded Schwarz-Schilling-Slovak Miroslav Lajčák and Austrian Valentin Inzko-in favor of well-meaning but ineffectual EU representatives committed to local ownership, despite repeated disappointments. The international financial crisis of 2008 stalled Bosnian economic growth, which remained fitful for close to a decade thereafter. The Americans followed the EU lead in agreeing to withdraw international judges and prosecutors from the judiciary and limiting use of the Bonn powers, leaving the High Representative in place but making it impossible for him to use them except in extremis. Only a serious Republika Srpska move to secede or other imminent risk of war would mobilize the kind of international reaction required for the 
High Representative to take vigorous action, but it is no longer clear that his decisions would be implemented. The EU representative, who dispenses lots of aid, is now the much more substantial force in Bosnia. But the EU prefers strategic patience-that means waiting for the Bosnians to do the right things - to aggressive action.

The European Commission speaks bluntly about Bosnia's need for a government with the powers needed to negotiate and implement EU membership and has deprived Sarajevo of tens of millions of euros because it has refused to reform, but at the same time it has sent new funds, and also offered Bosnia a shortcut to EU candidacy status, provided the country adopts labor market and other reforms. ${ }^{44}$ These are slowly making their way through various parliaments and the many levels of government required to enact them. The EU has also accepted a "coordination mechanism" that gives not only the entities but even the cantons within the Federation veto power. Implementation therefore lags and Bosnians remain essentially deadlocked on many important issues. ${ }^{45}$ Frustrated in their dealings with the Sarajevo government, the Europeans increasingly deal directly with the Republika Srpska government in Banja Luka, thus increasing its prominence and encouraging separatist inclinations. ${ }^{46}$

The results have been underwhelming. Dayton ended a war but failed to provide an adequate foundation for a warm peace or functional governance. Its constitutional power-sharing provisions ensure that ethnically based political parties govern and exploit a captured state and publicly owned companies for the benefit of their leaders. ${ }^{47}$ Corruption, cronyism, fake privatizations, and political appointments to public service positions, including the courts, are the rule rather than the exception. Hundreds of millions of dollars have been siphoned out of public companies into private pockets. More than ten years after failure of the April package, Bosnia is mired in ethnic nationalist polarization, even though Silajdžić has left the political scene. Repeated attempts at constitutional reform have failed. Dodik, still a political force, remains resistant, though American imposition of personal travel and financial sanctions against him has made him marginally more pliable than at times in the past. He has backed off scheduling referenda on the authority of the constitutional court and on Republika Srpska independence, but he is arming his police for war with Russian assistance. ${ }^{48}$

Today's Bosnia is a caricature of wartime Bosnia. Most of the Bosniak and Serb leaders make political hay by railing against each other. 
Nationalist Croats shift allegiance from side to side, depending on who is making the better offer, which is what they did during the war, especially in Mostar. More nationalist Croats also seek a "third entity," which would amount to a revival of Herzeg-Bosna, the wartime Croat parastate. Their most recent scheme in this regard is an effort at electoral reform that would reduce the electoral weight of Croats who live in Bosniak-majority cantons. ${ }^{49}$ The third entity was a bad idea at Dayton, when the Croats controlled arms flow into the Federation and contributed substantially to the Federation effort. Nor is it a good idea more than twenty years later. Creation of a Croat entity would necessarily result in formation of a land-locked, isolated, and likely radicalized Muslim entity (or two) in central Bosnia. Neither Croatia nor Serbia would like that.

The rest of the world would not either, but the internationals are also a shadow of their former selves, with the important exception of the Russians. The Americans lean toward the Bosniaks and strengthening the state government while weakening the group rights protected so strongly in the Dayton constitution. Belittling whatever initiative the Americans undertake, the Europeans have lowered the bar to begin accession talks in the hope that getting Bosnia into the membership process will fix everything. Turkey tries, with only occasional success, to play honest broker, though President Erdoğan's turn toward authoritarianism and Islamism has made him far chummier with the Bosniak member of the presidency, Bakir Izetbegović, the son of wartime leader Alija Izetbegović. The Russians support the Serbs and maximum autonomy for Republika Srpska, not the least to ensure that Bosnia never tries to enter NATO. Moscow is arming and training Republika Srpska's police far beyond the levels required to deal with the normal law-and-order problems arising in the entity. ${ }^{50}$

Little is solved, because Bosnia has a constitution that makes it difficult to solve anything without all three ethnic groups agreeing. There is little incentive for that to happen. Politicians who appeal across ethnic lines rarely win elections. When they do succeed, the ethnic nationalists from all three "constituent" peoples try to write new rules of the game to prevent a repetition. Their highly centralized political parties control patronage and jobs in public-sector companies. The country continues to claim to prepare for EU membership and even managed in 2010 to meet the requirements for visa-free travel to the Schengen Area. But it falls farther and farther behind the competition in the regatta to join the EU. 
Milorad Dodik visits Moscow frequently, stuffs his bank accounts with rubles, and jabbers about independence and sovereignty. It is not going to happen. Not even Serbia would recognize an independent Republika Srpska, much less incorporate it into Serbia, because that would end Belgrade's own hopes for EU membership.

Some Bosnian Croats insist on their own, ethnically defined entity. That is not going to happen either. ${ }^{51}$ The Bosnian Croats got a good deal at Dayton. If they have been unsuccessful at parlaying their constitutional position into real power, that is their problem, not anyone else's. They certainly should not get a better deal now that the war is over and the Herzegovinian stranglehold on access to central Bosnia has been broken.

Where does the solution lie? How can Bosnia's governance be unblocked and become more functional? Some hope it might come from the country's citizens. ${ }^{52}$ Dysfunctional and corrupt governance generated widespread protests and street-organized "plenums" in the winter and spring of 2014, forcing the resignations of some cantonal governments. The protests had the great virtue of raising issues that transcend ethnic divisions, even if they occurred mainly in Bosniak-majority areas of the Federation (due in part to repression in Republika Srpska). Nationalist Croat, Serb, and Bosniak politicians all tried to cast the protests as ethnically menacing, though they arguably demonstrated that Bosnian citizens of all ethnic groups want improved and less ethnically focused governance based on the creation of a "supra-ethnic citizenship identity of their participants" and a "secure space' for participatory democracy." 53

October 2014 elections were nevertheless inconclusive; the October 2018 polls were no more definitive. Modest shifts away from the ethnic nationalists have not yet deprived them of their decisive weight in parliament and in the two entities. Some hope for reform from the municipal level, where citizens can more easily turn out those politicians who do not produce benefits. ${ }^{54}$ Direct election of mayors, which Bosnia adopted in 2004, improved performance at that level, where issues-based, rather than ethnicity-based, politics are easier to pursue. Local government also has the virtue of allowing broader access to power, since numerical minorities are often majorities in some localities. Decentralization thereby shares power more broadly, without ethnic criteria and vetoes. But it can also be harder to find capable people and uncorrupted institutions. 
A lot now depends on the EU, especially Germany, the UK, and Croatia. If Angela Merkel were to do for Bosnia what we shall see she did eventually for Serbia-telling Bosnian leaders in clear terms what they need to do to make their candidacy for the EU a reality-that would help a great deal. The "reform" initiative in the fall of 2014 by London and Berlin fell far short of that. It may have merit, but it is unlikely to make a big political difference unless the international community does what is necessary to prevent crony privatizations. It would help if Zagreb, as it has done sometimes in the past, were to read the Bosnian Croats the riot act, telling them that their best bet is to use the one-third of the state that they gained at Dayton to strengthen Bosnia's governance and help it prepare for EU membership. But Croat ethnic nationalism, including in Zagreb, has grown more virulent in recent years, not less.

Many Bosnians, especially Bosniaks, look to the United States to do something, including deployment of U.S. troops. But the interventionist moment is over. Washington is worried about many other things and is not going to save Bosnia, unless its sovereignty or territorial integrity is seriously threatened. Washington wants Brussels to do the heavy lifting. There is not, in any event, a lot the Americans can do beyond trying to accelerate the reforms the EU is demanding, though helping the Bosnians to take another look at the April package and constitutional reform would also be a good idea. Bosnians need to look to themselves, to each other, to make a future that is better than their present.

Bosnia today is an unhappy place, but for the most part it is not a deadly one, and certainly not a genocidal one. Inter-ethnic violence is rare. Only a single American peacekeeper was killed in Bosnia after the war, despite many challenges. ${ }^{55} \mathrm{~A}$ few hundred European troops remain in the country, spread around in militarily insignificant units. The economy needs reform and the society needs greater ethnic integration. Democracy provides lots of opportunity for change, but citizens need to exercise their options to get it. If they don't, that is for them to decide. That is democracy too.

Could this persistently unhappy place return to war? Reversion of that sort happens in many countries. There is no ruling it out completely in Bosnia. But any future war there will be different from the 1990s episode. Yugoslavia is no longer falling apart. Milošević is gone. Politicians are still stoking ethnic tensions, which Dayton did little to attenuate. But the neighboring states are both more consolidated and more constrained now than they were then. While nationalist ambitions for Greater Serbia 
still reverberate, the nationalists who govern in Belgrade today have European aspirations that limit their appetite for intervention. As a member of both the EU and NATO, Croatia would likewise be under enormous pressure not to intervene in a new Bosnian war. The Sarajevo government has at its disposal, at least in theory, a small but well-trained and unified army. In the event of renewed fighting, its loyal components would likely be ordered to seize Brčko, which is the keystone of Republika Srpska. The outcome would depend on a likely days-long battle there.

Preventing such a scenario should be topmost on European and American minds. The Europeans should concentrate their troops in Brčko, where they would be a meaningful bulwark against both Republika Srpska independence and any effort to split the entity at its most vulnerable point. Britain added a few troops to the EU contingent in Bosnia in anticipation of the October 2018 elections, which generated political tension. Pleas for the United States to follow suit, or even to establish a permanent base in Bosnia, are likely to go unheard unless things get worse, because of commitments elsewhere. ${ }^{56}$

But things could get worse. Russia may be inclined to try its hand at destabilizing Bosnia by supporting Republika Srpska's independence ambitions. Dodik has been ready and willing to act as Moscow's agent, in return for political and financial support. Republika Srpska might join the Russian vassals in Georgia (South Ossetia and Abkhazia), Moldova (Transnistria), and Ukraine (Crimea, Donetsk, and Luhansk) as thorns in the side of the West that distract the respective suzerains from pursuing membership in NATO and the EU. This is an outcome Washington and Brussels need to work assiduously to avoid. How to do so is discussed in Chapter 6.

\section{Notes}

1. Andrew Wachtel and Christopher Bennett, "The Dissolution of Yugoslavia," in Confronting the Yugoslav Controversies: A Scholars' Initiative, ed. Charles W. Ingrao and Thomas A. Emmert (West Lafayette, IN: Purdue University Press, 2009), 13-47.

2. Louis Sell, Slobodan Milosević and the Destruction of Yugoslavia (Durham: Duke University Press, 2002), 170.

3. Karl Mueller, "The Demise of Yugoslavia and the Destruction of Bosnia: Strategic Causes, Effects, and Responses," in Deliberate Force: A Case 
Study in Effective Air Campaigning: Final Report of the Air University Balkans Air Campaign Study, ed. Robert C. Owen (Maxwell AFB, AL: Air University Press, 2000), 10, http://www.au.af.mil/au/awc/ awcgate/au/owen.pdf.

4. Anto Knežević, “Alija Izetbegović’s 'Islamic Declaration': Its Substance and Its Western Reception," Islamic Studies 36, nos. 2/3 (1997): 483521, http://www.jstor.org/stable/23076209.

5. Gale Stokes, "Independence and the Fate of Minorities, 1991-1992," in Ingrao and Emmert, Confronting the Yugoslav Controversies, 83-112.

6. Richard Caplan, Europe and the Recognition of New States in Yugoslavia (Cambridge: Cambridge University Press, 2005).

7. "The Conflicts," International Criminal Tribunal for the Former Yugoslavia, http://www.icty.org/en/about/what-former-yugoslavia/conflicts.

8. The failure of these efforts is discussed extensively by James E. Goodby in "When War Won Out: Bosnian Peace Plans before Dayton," International Negotiation 1, no. 3 (1996): 501-23.

9. Josip Glaurdic, The Hour of Europe: Western Powers and the Breakup of Yugoslavia (New Haven: Yale University Press, 2011).

10. Matjaž Klemenčič, "The International Community and the FRY/ Belligerents, 1989-1997," in Ingrao Emmert, Confronting the Yugoslav Controversies, 177-80.

11. Marko Attila Hoare, How Bosnia Armed (London: Saqi Books, 2004).

12. John Pomfret and David B. Ottaway, "U.S. Allies' Arms Aid to Bosnia Detailed," Los Angeles Times, May 12, 1996, http://articles.latimes. com/1996-05-12/news/mn-3437_1_arms-smuggling.

13. Adrian Shtuni, "The Western Balkans: A Jihadist Pipeline to Syria and Iraq," Fikra Forum, January 29, 2015.

14. Richard C. Holbrooke, To End a War (New York: Random House, 1998), 296.

15. My role in making the Bosnian Federation real is recounted in Daniel Serwer, "A Bosnian Federation Memoir," in Herding Cats: Multiparty Mediation in a Complex World, ed. Chester A. Crocker, Fen Osler Hampson, and Pamela R. Aall (Washington, DC: United States Institute of Peace Press, 1999), 547-86.

16. Derek Chollet, The Road to the Dayton Accords: A Study of American Statecraft (New York: Palgrave Macmillan, 2005).

17. Tim Ripley, Operation Deliberate Force: The UN and NATO Campaign in Bosnia 1995 (Lancaster, UK: Centre for Defence and International Security Studies, 1999), 268.

18. For a compelling statement of this perspective, see Peter W. Galbraith, "Washington, Erdut and Dayton: Negotiating and Implementing Peace in Croatia and Bosnia-Herzegovina," Cornell International Law Journal 
30, no. 3 (1997): 643-49, https://scholarship.law.cornell.edu/cgi/viewcontent.cgi?referer=https:/ / www.bing.com/\&httpsredir $=1$ \&article $=$ 1408\&context $=$ cilj.

19. Holbrooke, To End a War, 197.

20. I discussed some of the issues treated here in "Dayton Reexamined," Axess Magasin, June 2013, 25-27.

21. AmEmbassy Belgrade 2419 to SecState, May 19, 1995, paragraph 4, https://www.peacefare.net/state-department-belgrade-cables-1995/.

22. Sell, Milošević and the Destruction of Yugoslavia, 216.

23. Adam LeBor, Milošević: A Biography (New Haven: Yale University Press, 2004), 245.

24. AmEmbassy Belgrade 823 to SecState, February 17, 1995, paragraph 5, https://www.peacefare.net/state-department-belgrade-cables-1995/.

25. Sell, Milošević and the Destruction of Yugoslavia, 245.

26. AmEmbassy Belgrade 2468 to SecState, May 22, 1995, https://www.peacefare.net/state-department-belgrade-cables-1995/; LeBor, Milošević, 246.

27. Daniel W. Drezner, The Sanctions Paradox: Economic Statecraft and International Relations (Cambridge: Cambridge University Press, 2000).

28. Agency for Statistics of Bosnia and Herzegovina, "Cenzus [sic] of Population, Households and Dwellings in Bosnia and Herzegovina, 2013: Final Results," Sarajevo, June 2016, http://www.popis2013.ba/ popis2013/doc/Popis2013prvoIzdanje.pdf.

29. Private conversation with the author at Dayton in November 1995.

30. Holbrooke, To End a War, 309.

31. James Kennedy and Liliana Riga, "A Liberal Route from Homogeneity? US Policymakers and the Liberalization of Ethnic Nationalists in Bosnia's Dayton Accords," Nationalism and Ethnic Politics 19, no. 2 (2013): 163-86, https://www.tandfonline.com/doi/abs/10.1080/ 13537113.2013.788910? journalCode $=$ fnep20.

32. The author heard this from an American official present at the time.

33. Barbara F. Walter, Committing to Peace: The Successful Settlement of Civil Wars (Princeton: Princeton University Press, 2002).

34. Steven L. Burg and Paul S. Shoup, The War in Bosnia-Herzegovina: Ethnic Conflict and International Intervention (Armonk, NY: M. E. Sharpe, 1999), 172.

35. The initial shortcomings, especially the compromises with ethnic nationalism, were apparent at the time. See Jane M.O. Sharp, "Dayton Report Card," International Security 22, no. 3 (Winter 1996/98): 101-37, and somewhat later, Richard Caplan, "Assessing the Dayton Accord: The Structural Weaknesses of the General Framework Agreement for Peace in Bosnia and Herzegovina," Diplomacy and Statecraft 11, no. 2 (July 2000): 213-32. 
36. Oscar Vera and Karmen Fields, "Bosnia-Herzegovina: The Third Entity Movement," in Criminalized Power Structures: The Overlooked Enemies of Peace, ed. Michael Dziedzi (Lanham, MD: Rowman \& Littlefield, 2016), 27-51.

37. "GNI per Capita, Atlas Method, Bosnia and Herzegovina (1996-2016)," The World Bank, 2016, https://data.worldbank.org/indicator/NY.GNP. PCAP.CD ?locations=BA.

38. "Secretary-General Strongly Endorses Decision to Create Brčko District of Bosnia and Herzegovina: Meetings Coverage and Press Releases," United Nations, March 1999, https://www.un.org/press/ en/1999/19990305.sgsm6917.html.

39. Robert William Farrand and Allison Frendak-Blume, Reconstruction and Peace Building in the Balkans: The Brčko Experience (Lanham, MD: Rowman \& Littlefield, 2011).

40. European Commission for Democracy through Law (Venice Commission), Opinion on the Constitutional Situation in Bosnia and Herzegovina and the Powers of the High Representative, March 11, 2005, http://www.venice.coe.int/webforms/documents/default.aspx?pdffile= CDL-AD(2005)004-e.

41. Don Hays and Jason Crosby, From Dayton to Brussels: Constitutional Preparations for Bosnia's EU Accession (Washington, DC: United States Institute of Peace Press, 2006), https://www.usip.org/publications $/ 2006 / 10 /$ dayton-brussels-constitutional-preparations-bosnias-euaccession.

42. Gerald Knaus and Felix Martin, "Lessons from Bosnia and Herzegovina: Travails of the European Raj," Journal of Democracy 18, no. 5 (2003): 60-74, https://www.journalofdemocracy.org/article/lessons-bosniaand-herzegovina-travails-european-raj.

43. Judgment delivered by a Grand Chamber, Sejdić and Finci v. Bosnia and Herzegovina, nos. 27796/06 and 34836/06, ECHR (2009), https:// www.opensocietyfoundations.org/sites/default/files/grand-chamber-judgment-20091222.pdf.

44. Frank-Walter Steinmeier and Philip Hammond to Federica Mogherini and Johannes Hahn, Berlin/London, November 4, 2014, http://infographics.economist.com/20141108_Letter/Letter.pdf.

45. Bobo Weber, "Substantial Change on the Horizon? A Monitoring Report on the EU's New Bosnia and Herzegovina Initiative," Democratization Policy Council (Berlin-Sarajevo, March 2017), https://ba.boell. org/bs/2017/04/03/substantial-change-horizon-monitoring-report-eus-new-bosnia-and-herzegovina-initiative.

46. Some even propose separate EU accession for Republika Srpska: Doğa Ulaş Eralp, Politics of the European Union in Bosnia-Herzegovina: Between Conflict and Democracy (Lanham, MD: Lexington Books, 2012). 
47. Srdjan Blagovcanin and Boris Divjak, How Bosnia's Political Economy Holds It Back and What to Do About It (Washington, DC: Center for Transatlantic Relations, Johns Hopkins School of Advanced International Studies, 2015), https://www.peacefare.net/wp-content/ uploads/2015/08/Blagovcanin-and-Divjak_final.pdf.

48. Reuf Bajrovic, Raichard Kraemer, and Emir Suljagic, "Bosnia on the Russian Chopping Block: The Potential for Violence and Steps to Prevent It," Foreign Policy Research Institute, March 2018, https://www.fpri. org/article/2018/03/bosnia-russian-chopping-block-potential-violencesteps-prevent/.

49. Zeljana Zovko, "Wanted: Even-Handed US Engagement in Bosnia and Herzegovina," The Atlantic Council, February 2018, http:// www.atlanticcouncil.org/blogs/new-atlanticist/wanted-even-handedus-engagement-in-bosnia-and-herzegovina.

50. Reuf Bajrovic, Raichard Kraemer, and Emir Suljagic, "Bosnia on the Russian Chopping Block: The Potential for Violence and Steps to Prevent It," Foreign Policy Research Institute, March 2018, https://www.fpri. org/article/2018/03/bosnia-russian-chopping-block-potential-violencesteps-prevent/.

51. Daniel Serwer, "Bosnia Needs to Get Boring," Peacefare.net, October 12, 2014, https://www.peacefare.net/2014/10/12/.

52. Jasmin Mujanović, Hunger and Fury the Crisis of Democracy in the Balkans (London: Hurst, 2018).

53. Nina Belyaeva, "Citizen Plenums in Bosnia Protests: Creating a Postethnic Identity," in Non-Western Social Movements and Participatory Democracy, ed. Ekim Arbatli and Diana Rosenberg (Cham: Springer, 2017), 115-38.

54. "Municipalization: A Popular Governance Model for Bosnia and Herzegovina, Revised Model," Coalition 143 (K-143), June 24, 2014, https://www.scribd.com/document/231194321/K-143-Municipalization-Model-FULL-document-ENG.

55. Center for Military History, "Bosnia-Herzegovina: The U.S. Army's Role in Peace Enforcement Operations 1995-2004," CMH Pub 70-97-1, https://history.army.mil/html/books/070/70-97-1/cmhPub_70-97-1. pdf.

56. Damir Marusic, Sarah Bedenbaugh, and Damon Wilson, "Balkans Forward: New US Strategy for the Region," The Atlantic Council, November 2017, http://www.atlanticcouncil.org/images/Balkans_ Forward_web_1128.pdf. 
Open Access This chapter is distributed under the terms of the Creative Commons Attribution 4.0 International License (http://creativecommons.org/ licenses/by/4.0/), which permits use, duplication, adaptation, distribution and reproduction in any medium or format, as long as you give appropriate credit to the original author(s) and the source, a link is provided to the Creative Commons license and any changes made are indicated.

The images or other third party material in this chapter are included in the work's Creative Commons license, unless indicated otherwise in the credit line; if such material is not included in the work's Creative Commons license and the respective action is not permitted by statutory regulation, users will need to obtain permission from the license holder to duplicate, adapt or reproduce the material.

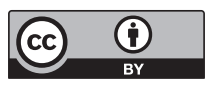

